\title{
Diagnostic accuracy of total macular and ganglion cell layer thickness in differentiating different stages of glaucoma: an SD-OCT study
}

Lee Wen Yee ${ }^{1}$, Norlina Mohd Ramli ${ }^{1}$, Amir Samsudin ${ }^{1}$, Mimiwati binti Zahari ${ }^{1}$, Azida Juana binti Wan Ab Kadir ${ }^{1}$, Farrah Jaafar ${ }^{2}$, Ahmad Mt Saad ${ }^{2}$

${ }^{1}$ Ophthalmology Department, University Malaya Medical Centre, Kuala Lumpur, Malaysia: ${ }^{2}$ Ophthalmology Department, Hospital Sultanah Bahiyah, Alor Setar, Kedah, Malaysia

\section{Abstract}

Purpose: To determine the diagnostic accuracy of mean macular retinal thickness $(\mathrm{mRT})$ and macular ganglion cell layer $(\mathrm{mGCL})$ thickness measured by Spectralis spectral-domain optical coherence tomography (SD-OCT) posterior pole thickness map (PPTM) in differentiating between normal and glaucoma eyes of different severity.

Study design: Cross-sectional study.

Methods: All subjects were divided into normal and glaucoma groups according to the visual fields-based Glaucoma Staging System. They underwent slit-lamp examination, Humphrey visual field test, and SD-OCT (PPTM) imaging. mRT and $\mathrm{mGCL}$ thickness measurements were recorded. Analysis of variance with the least significant difference post hoc test was used for pairwise comparison. Ability to discriminate between normal eyes and those with differing severity of glaucoma was assessed using the area under the receiver operating characteristic curve (AUROC). Results: A total of 201 eyes from 201 subjects were enrolled in this study. The mean $\mathrm{mRT}$ in the normal population, mild-moderate glaucoma, and advanced-severe

Correspondence: Dr. Norlina Binti Mohd Ramli, MsOphth (UM), Ophthalmology

Department, University Malaya Medical Centre, Lembah Pantai, 59100 Kuala Lumpur, Malaysia.

E-mail: norlina@ummc.edu.my 
glaucoma was $290.2 \pm 12.1 \mu \mathrm{m}, 270.1 \pm 17.0 \mu \mathrm{m}$, and $259.1 \pm 15.0 \mu \mathrm{m}$, respectively. Mean mGCL thickness for the corresponding three groups was $32.3 \pm 2.8 \mu \mathrm{m}$, $27.6 \pm 3.3 \mu \mathrm{m}$ and $22.2 \pm 3.8 \mu \mathrm{m}$, respectively. AUROC analysis showed excellent diagnostic discrimination between glaucoma and normal subjects for mRT (AUC: 0.90) and mGCL thickness (AUC: 0.92). The cut-off value of mRT was $274.9 \mu \mathrm{m}(90 \%$ sensitivity, $75 \%$ specificity) and of mGCL thickness was $27.9 \mu \mathrm{m}$ (93\% sensitivity, $74 \%$ specificity). The discrimination ability performance of $\mathrm{mRT}$ and $\mathrm{mGCL}$ thickness deteriorated with increasing severity of glaucoma with $\mathrm{MGCL}$ thickness (AUC: 0.67-0.87) performing slightly better than mRT for all grades (AUC: 0.58-0.71). Conclusions: $\mathrm{mRT}$ and $\mathrm{mGCL}$ thickness measurement on PPTM showed great sensitivity and specificity to discern between normal and glaucomatous subjects. The discrimination ability of $\mathrm{mRT}$ and $\mathrm{mGCL}$ thickness, however, decreases with increasing grade of glaucoma. We believe SD-OCT PPTM offers an alternative imaging method to detect early glaucoma.

Keywords: glaucoma, glaucoma grading system, macular ganglion cell layer (mGCL), macular retinal thickness (mRT), spectral domain optical coherence tomography (SD-OCT)

\section{Abstrak}

Tujuan: Untuk menentukan ketepatan diagnostik di antara pesakit glaukoma dan normal (bukan glaukoma) berdasarkan purata ketebalan macular retina macular ("macular retinal thickness" [mRT]) dan lapisan sel ganglion makular ("macular ganglion cell layer" [mGCL)]) yang diukur oleh tomografi optikal koheren spektral domain ("spectral-domain optical coherence tomography" [SD-OCT]) (Spectralis) pada peta ketabalan polar posterior ("Posterior Pole Thickness Map" [PPTM]).

Reka betuk kajian: Kajian keratan rentas.

Kaedah kajian: Subjek dibahagikan kepada dua kumpulan: glaukoma dan normal berdasarkan skor ke atas medan penglihatan mengikut sistem tahap glaukoma (“Glaucoma Staging System” [GSS]).

Kesemua subjek telah menjalani pemeriksaan slitlamp, ujian medan penglihatan (Humphrey), dan pengimejan tomografi SD-OCT (PPTM). Ukuran mRT dan mGCL dibuat dan direkodkan. Perbandingan secara berpasangan dibuat menggunakan ujian analisa varians dengan perbezaan yang paling ketara secara post-hoc. Keupayaan untuk mendiskriminasi antara normal dan pelbagai tahap keterukkan glaukoma diuji dengan ujian statistik menentukan Kawasan dibawah lengkung karakter operasi penerima ("area under the receiver operating characteristic curve" [AUROC]).

Keputusan: Kajian ini melibatkan 201 mata daripada 201 subjek. Purata mRT dalam kumpulan normal dan kumpulan glaukoma secara berpasangan tahap keterukan 
ringan-sederhana dan teruk adalah $290.2 \pm 12.1 \mu \mathrm{m}, 270.1 \pm 17.0 \mu \mathrm{m}$ dan $259.1 \pm$ $15.0 \mu \mathrm{m}$. Purata ketebalan mGCL untuk tiga kumpulan yang sepadan adalah $32.3 \pm$ $2.8 \mu \mathrm{m}, 27.6 \pm 3.3 \mu \mathrm{m}$ dan $22.2 \pm 3.8 \mu \mathrm{m}$. Analisa AUROC menunjukkan diskriminasi diagnostik yang sangat baik untuk glaukoma dan subjek biasa untuk mRT (AUC: 0.90) dan ketebalan mGCL (AUC:0.92). Penetapan nilai mRT adalah $274.9 \mu \mathrm{m}$ (pada tahap $90 \%$ sensitiviti, $75 \%$ spesifikasi) dan ketebalan mGCL adalah $27.9 \mu \mathrm{m}$ (93\% sensitiviti, $74 \%$ spesifikasi). Keupayaan diskriminator mRT dan ketebalan mGCL merosot dengan peningkatan tahap keterukan glaucoma. Manakala purata ketebalan mGCL (AUC: 0.67-0.87) menunjukkan keupayaan diskriminator lebih baik daripada purata mRT (AUC: 0.58-0.71) untuk semua tahap keterukkan glaucoma.

Kesimpulan: Pengukuran ketebalan mRT dan mGCL dengan PPTM menunjukkan sensitiviti dan spesifikasi yang tinggi dalam membezakan antara glaukoma dan bukan glaukoma. Keupayaan diskriminator mRT dan ketebalan mGCL, bagaimanapun, berkurangan dengan peningkatan keterukkan glaukoma. SD-OCT PPTM menawarkan kaedah pengimejan alternatif untuk mengesan glaukoma pada peringkat awal.

Kata kekunci: glaukoma, ketebalan retinal makular, lapisan sel ganglion makular, sistem penggredan glaukoma, spectral-domain optical coherence tomography

\section{Introduction}

Glaucoma is a complex multi-factorial disorder characterised by progressive loss of retinal ganglion cell, axons, nerve fibre layer, and visual field loss. ${ }^{1}$ Macular thickness is correspondingly reduced in glaucomatous eyes with the ganglion cell layer particularly affected. ${ }^{2}$ Previous studies have been done to determine macular thickness in glaucoma patients using the modified Early Treatment of Diabetic Retinopathy Study macular map..$^{3-6}$ However, with the spectral-domain optical coherence tomography (SD-OCT) posterior pole thickness map (PPTM) available from Spectralis (Heidelberg Engineering, Carlsbad, CA, USA), a larger area of the macula is captured, enabling assessment of changes in the glaucoma disease process.

The Early Treatment of Diabetic Retinopathy Study macular map only covers a small area $(6 \mathrm{~mm})$ of the macula, centred around the fovea, which is equivalent to a $10^{\circ}$ visual field test. ${ }^{3-7}$ The PPTM covers a larger area $(9 \mathrm{~mm})$ of the macula and is comparable with the central $4 X 4$ points among the 52 test points of the $24-2$ visual field test. ${ }^{8,9}$ The colour scale of the PPTM is finer than the existing Early Treatment of Diabetic Retinopathy Study macular map and is sensitive to change in thickness as small as $1 \mu \mathrm{m} .{ }^{10}$ Theoretically, the PPTM will perform better in diagnosing glaucoma based on macular thickness, as the projection of retinal ganglion cell 
axons follows the horizontal raphe and scanning larger macular areas theoretically provide more practical information. ${ }^{11}$ Isolation of the ganglion cell layer should enhance the diagnostic power of the macular imaging as it gets rid of the disparity caused by the outer retinal layers. ${ }^{4}$

This study was conducted to determine the diagnostic accuracy of the total macular and ganglion cell layer thickness measured by PPTM using SD-OCT in differentiating between normal eyes and those with different severity of glaucoma.

\section{Methods}

This was a cross-sectional study conducted from May 2018 to May 2019. Ethical approval was obtained prior to the commencement of the study from the Medical Research \& Ethics Committee (NMRR-18-458-39979). Informed consent was obtained from all participants. It was conducted in accordance with the Declaration of Helsinki.

All subjects underwent thorough ophthalmic examination, including best-corrected visual acuity (BCVA), slit-lamp examination, intraocular pressure measurement using Goldmann applanation tonometry, dilated fundus, and optic disc assessment. Visual field test was performed using the Humphrey Field Analyzer (Carl Zeiss Meditec, Dublin, CA, USA) with the central 24-2 pattern of the Swedish Interactive Threshold Algorithm standard strategy. The visual field results were considered reliable when false-positive and negative errors were $<33 \%$ and fixation losses were $<20 \% .{ }^{8}$ One eye from each subject was randomly selected if both eyes were eligible.

The eligible eyes were categorized into normal or different severity of glaucoma. All normal subjects had to fulfil the following inclusion criteria: age above 20 years, no history of glaucoma in the family or chronic corticosteroid use, BCVA $\geq 6 / 12$, no abnormality on ocular examination, intraocular pressure $\leq 21 \mathrm{mmHg}$, normal optic nerve head appearance, and normal 24-2 Swedish Interactive Threshold Algorithm-standard Humphrey visual field test (mean deviation and pattern standard deviation within $95 \%$ confidence limits, with fewer than three non-edge contiguous points within the same hemifield identified as significant $(P<0.05)$ in the pattern deviation plot, and glaucoma hemifield test results within normal limits). ${ }^{4}$

The glaucoma subjects were divided into four subgroups: mild (mean deviation better than $-6.00 \mathrm{~dB}$ ), moderate (mean deviation $-6.01 \mathrm{~dB}$ to $-12.00 \mathrm{~dB}$ ), advanced (mean deviation $-12.01 \mathrm{~dB}$ to $-20.00 \mathrm{~dB}$ ), and severe (mean deviation $-20.01 \mathrm{~dB}$ or worse) according to the visual field-based Glaucoma Staging System (Stages 1-4 of the Bascom Palmer [Hodapp-Anderson-Parrish] Glaucoma Staging System). ${ }^{12}$ All glaucoma subjects had to fulfil the following inclusion criteria: glaucomatous appearance of the optic disc. ${ }^{13}$ and retinal nerve fibre layer defect corresponding with typical reproducible visual field defects. All glaucoma subjects had confirmed 


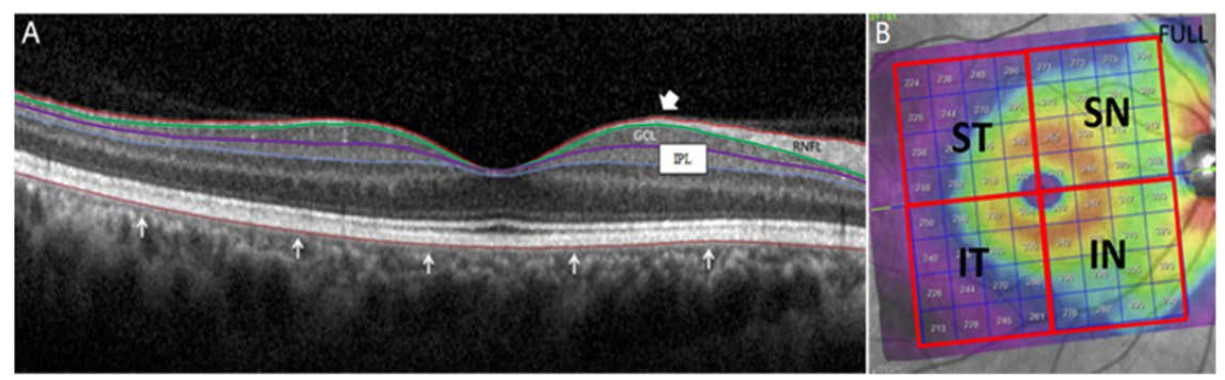

Fig. 1. (A) Segmentation of the retinal layers with Glaucoma Premium Module Edition software on a normal subject. Macular retinal thickness (mRT) is between the white block arrowhead and white arrows. White block arrowhead: inner limiting membrane; white arrows: outer border of the retinal pigment epithelium. Macular ganglion cell layer ( $\mathrm{mGCL}$ ) is the hyporeflective layer between the green and purple lines. Green line: outer border of the retinal nerve fibre layer (RNFL); purple line: outer border of the inner plexiform layer (IPL). $(B)$ Color-coded map of PPTM, $8 \times 8$ grid centred on the foveal pit and aligned to the fovea-disc axis. Posterior pole is divided into quadrants. ST: superior temporal; SN: superior nasal; IT: inferior temporal; IN: inferior nasal.

diagnosis for more 6 six months and performed at least three previous reliable visual fields. All patients with open- and closed-angle primary glaucoma were included.

Exclusion criteria for all groups were: coexisting ocular or systemic disease that could cause visual field loss; disability, mental or other, that could prevent the correct understanding of the information needed for informed consent; refractive error of more than \pm 3 dioptres (D); media opacities; and any pathology or prior procedures that could affect macular thickness such as diabetic retinopathy, macular degeneration, epiretinal membrane, previous ocular surgery for macular disorder, and retinal laser procedures. Subjects with unreliable visual fields were also excluded.

All the subjects underwent retinal imaging with the Spectralis SD-OCT using the Glaucoma Module Premium Edition software on the same day as the visual field test to obtain the macular retinal thickness (mRT) and macular ganglion cell layer (mGCL) thickness. SD-OCT images were acquired in a dark room by the same experienced operator on dilated pupil using image alignment eye-tracking software (TruTrack; Heidelberg Engineering); an internal fixation target was used to provide the highest reproducibility of the images. Through the automated real-time function of the SD-OCT device, each B-scan was repeated nine to eleven times to improve the quality of the images. ${ }^{10}$ PPTM can measure the macular thickness at the central $20^{\circ}$ of the posterior pole $(9 \mathrm{~mm})$ using 61 horizontal B-scans $\left(30^{\circ} \times 25^{\circ}\right.$ OCT volume scan). Segmentation of the retinal layers was performed automatically by the Spectralis SD-OCT software. ${ }^{9,14}$ The quality of the scans was assessed and scans with a quality score of less than $25 \mathrm{~dB}$, any visible motion or blinking artifacts, and any detected macular pathology were rejected. 
The PPTM displays the retinal thickness in the respective cell of the grid. Mean $\mathrm{mRT}$ and $\mathrm{mGCL}$ thickness were calculated automatically and further divided into mean thickness at the superior and inferior hemispheres. Data of retinal thickness values in each square cell of the total 64 square cells were collected and the mean was calculated based on different quadrants of posterior pole (Fig. 1).

\section{Statistical analysis}

The normality of data was assessed using the Kolmogorov-Smirnov and Shapiro-Wilk tests. Categorical variables were analysed using either the Kruskal-Wallis or Chi-square test. Analysis of variance with the least significant difference post hoc test was used for pairwise comparison. The diagnostic capabilities and accuracy of each variable to differentiate between normal and glaucoma eyes of different severity were determined by calculating the area under the receiver operating characteristic curve (AUROC). The receiver operating characteristic curve shows the trade-off between sensitivity and specificity. Statistical analysis was performed using Statistical Package for the Social Sciences version 21.0 (IBM, USA). A $P$-value of $<0.05$ was considered as statistically significant.

\section{Results}

During the study period, 218 subjects underwent a comprehensive examination and satisfied the inclusion and exclusion criteria in the study. Seventeen eyes were excluded due to poor image quality on OCT $(n=8)$, non-clinically detectable small serous pigment epithelial detachment $(n=2)$, presence of minor retinal pigment epithelial irregularities $(n=4)$, and epiretinal membrane $(n=3)$. This left a remainder of 201 eyes, which was almost equally divided among the five groups. The demographic and clinical characteristics of the normal and glaucoma groups are shown in Table 1. The glaucomatous eyes in this study included 126 eyes $(78.3 \%)$ with open-angle glaucoma and 35 eyes $(21.7 \%)$ with angle-closure glaucoma. Open-angle glaucoma groups included patients with primary open-angle glaucoma (82.2\%) and normal-tension glaucoma (17.8\%). All subjects in the angle-closure glaucoma group were primary angle-closure glaucoma and the majority of subjects (82.3\%) were chronic angle-closure glaucoma, while acute angle-closure glaucoma subjects accounted for $17.7 \%$.

Mean $\mathrm{mRT}$ and $\mathrm{mGCL}$ thickness in the normal population and the different grades of glaucoma are shown in Figure 2. Decreasing thickness was noted with increasing severity of glaucoma. Mean $\mathrm{mRT}$ in the normal, mild-moderate, and advanced-severe glaucoma groups was $290.2 \pm 12.1 \mu \mathrm{m}, 270.1 \pm 17.0 \mu \mathrm{m}$, and $259.1 \pm 15.0 \mu \mathrm{m}$, respectively, while mean $\mathrm{mGCL}$ thickness was $32.3 \pm 2.8 \mu \mathrm{m}, 27.6$ $\pm 3.3 \mu \mathrm{m}$, and $22.2 \pm 3.8 \mu \mathrm{m}$, respectively. The difference between the groups was statistically significant $(P<0.001)$. 
Table 1. Demographic and clinical characteristics of normal and glaucoma groups

\begin{tabular}{|c|c|c|c|c|c|c|}
\hline & & Glaucom & $n=161)$ & & & \\
\hline & Normal & $\begin{array}{l}\text { Mild } \\
(n=40)\end{array}$ & $\begin{array}{l}\text { Moderate } \\
(n=41)\end{array}$ & $\begin{array}{l}\text { Advanced } \\
(n=40)\end{array}$ & $\begin{array}{l}\text { Severe } \\
(n=40)\end{array}$ & $P$-value \\
\hline Age (years) & $\begin{array}{l}62.00 \\
(54.25- \\
70.00)\end{array}$ & $\begin{array}{l}65.85 \\
(62.86- \\
68.84)\end{array}$ & $\begin{array}{l}69.85(67.62 \\
-72.08)\end{array}$ & $\begin{array}{l}64.10(60.92 \\
-67.28)\end{array}$ & \begin{tabular}{|l}
61.38 \\
$(56.62-$ \\
$66.23)$
\end{tabular} & $0.112^{\mathrm{a}}$ \\
\hline $\begin{array}{l}\text { Male/ } \\
\text { Female } \\
(n / n)\end{array}$ & $14 / 26$ & $25 / 15$ & $26 / 15$ & $25 / 15$ & $29 / 11$ & $0.001^{b}$ \\
\hline $\begin{array}{l}\text { IOP } \\
\text { (mmHg) }\end{array}$ & $17.1 \pm 1.6$ & $16.2 \pm 3.2$ & $15.1 \pm 2.5$ & $14.3 \pm 1.2$ & $15.3 \pm 1.1$ & $0.330^{\mathrm{a}}$ \\
\hline VF MD (dB) & $\begin{array}{l}-1.20 \\
(-2.26 \pm \\
1.55)\end{array}$ & $\begin{array}{l}-2.76 \\
(-3.79- \\
-1.87)\end{array}$ & $\begin{array}{l}-6.17 \\
(-8.38- \\
-5.16)\end{array}$ & $\begin{array}{l}-14.05 \\
(-16.39- \\
-11.98)\end{array}$ & $\begin{array}{l}-23.42 \\
(-26.70- \\
-21.62)\end{array}$ & $<0.001^{a}$ \\
\hline $\begin{array}{l}\text { VF PSD } \\
\text { (dB) }\end{array}$ & $1.55 \pm 0.2$ & $2.17 \pm 0.4$ & $5.30 \pm 0.3$ & $12.25 \pm 0.1$ & $13.45 \pm 0.2$ & $<0.001^{\mathrm{a}}$ \\
\hline $\begin{array}{l}\text { Refraction } \\
\text { (D) }\end{array}$ & $\begin{array}{l}-2.81 \pm \\
1.58\end{array}$ & $\begin{array}{l}-1.65 \pm \\
2.08\end{array}$ & $-1.85 \pm 0.55$ & $-2.05 \pm 1.75$ & $\begin{array}{l}-2.55 \pm \\
1.55\end{array}$ & $0.820^{a}$ \\
\hline
\end{tabular}

IOP: intraocular pressure; VF: visual field; MD: mean deviation; PSD: pattern standard deviation

aKruskal-Wallis test

${ }^{\mathrm{b}} \mathrm{Chi}$-square Test

In both the normal and glaucoma groups, mean mRT and mGCL thickness were highest at the superior nasal quadrant, followed by the inferior nasal, superior temporal, and inferior temporal quadrants. Overall, the superior hemisphere was thicker compared to the inferior hemisphere. There was a significant decrease in thickness from the normal group to the glaucoma groups in all quadrants (Table 2).

The receiver operating curve analysis showed excellent diagnostic discrimination for glaucoma and normal subjects for mean mRT (AUROC: 0.901) and mGCL thickness (AUROC: 0.929). Cut-off values of less than $274.9 \mu \mathrm{m}$ for mean mRT and less than $27.9 \mu \mathrm{m}$ for $\mathrm{mGCL}$ thickness were highly sensitive and specific for the diagnosis of glaucoma (Fig. 3). 

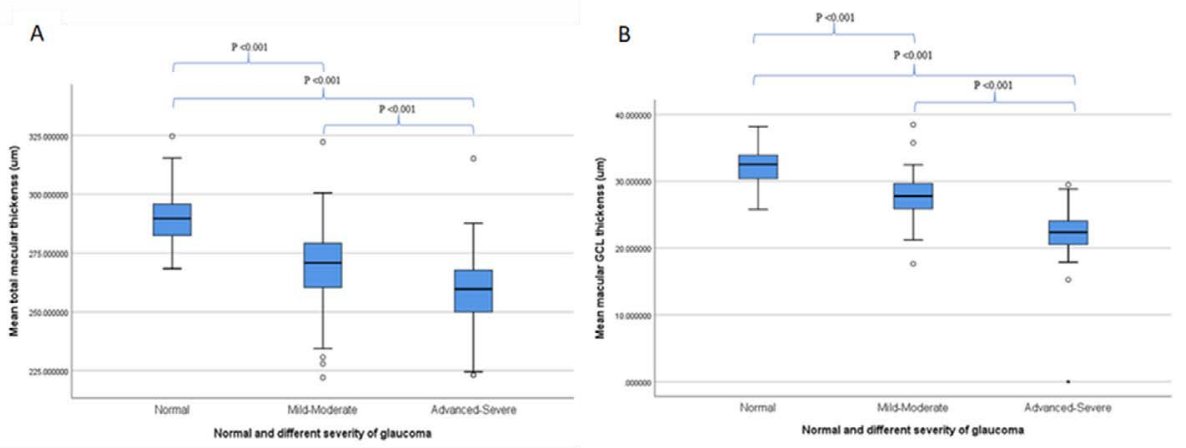

Fig. 2. Box-and-whisker plots showing the distribution of mean macular retinal thickness $(A)$ and mean macular ganglion cell layer thickness $(B)$ for normal and glaucoma eyes of different severity.

Table 2. Mean macular retinal thickness and macular ganglion cell layer thickness according to different quadrants of posterior pole in normal and different severity of glaucoma groups

\begin{tabular}{|c|c|c|c|c|c|c|c|}
\hline \multicolumn{8}{|l|}{ Mean mRT } \\
\hline \multirow[b]{2}{*}{ Quadrant } & \multicolumn{2}{|l|}{ Normal } & \multicolumn{2}{|c|}{$\begin{array}{l}\text { Mild-moderate } \\
\text { glaucoma }\end{array}$} & \multicolumn{2}{|c|}{$\begin{array}{l}\text { Advanced- } \\
\text { severe glaucoma }\end{array}$} & \multirow[b]{2}{*}{$P$-value } \\
\hline & $\begin{array}{l}\text { Mean } \\
\pm S D \\
(\mu \mathrm{m})\end{array}$ & $\begin{array}{l}95 \% \mathrm{Cl} \\
(\mu \mathrm{m})\end{array}$ & $\begin{array}{l}\text { Mean } \\
\pm S D \\
(\mu \mathrm{m})\end{array}$ & $\begin{array}{l}95 \% \mathrm{Cl} \\
(\mu \mathrm{m})\end{array}$ & $\begin{array}{l}\text { Mean } \pm \\
\text { SD }(\mu \mathrm{m})\end{array}$ & $\begin{array}{l}95 \% \mathrm{Cl} \\
(\mu \mathrm{m})\end{array}$ & \\
\hline SN & $\begin{array}{l}310.1 \pm \\
16.1^{\dagger \ddagger}\end{array}$ & $\begin{array}{l}304.9- \\
315.2\end{array}$ & $\begin{array}{l}292.3 \pm \\
24.3^{\dagger \S}\end{array}$ & $\begin{array}{l}287.0- \\
297.7\end{array}$ & $\begin{array}{l}277.4 \pm \\
17.6^{\ddagger \S}\end{array}$ & $\begin{array}{l}273.5- \\
281.3\end{array}$ & $<0.001$ \\
\hline IN & $\begin{array}{l}306.3 \pm \\
17.1^{\dagger \ddagger}\end{array}$ & $\begin{array}{l}300.8- \\
311.8\end{array}$ & $\begin{array}{l}278.5 \pm \\
26.0^{\dagger \S}\end{array}$ & $\begin{array}{l}272.7- \\
284.2\end{array}$ & $\begin{array}{l}263.2 \pm \\
29.3^{\ddagger \S}\end{array}$ & $\begin{array}{l}256.7- \\
269.8\end{array}$ & $<0.001$ \\
\hline ST & $\begin{array}{l}273.4 \pm \\
11.3^{\dagger \ddagger}\end{array}$ & $\begin{array}{l}269.8- \\
277.0\end{array}$ & $\begin{array}{l}259.5 \pm \\
13.2^{\dagger \S}\end{array}$ & $\begin{array}{l}256.6- \\
262.4\end{array}$ & $\begin{array}{l}252.8 \pm \\
13.1^{\ddagger \S}\end{array}$ & $\begin{array}{l}249.8- \\
255.7\end{array}$ & $<0.001$ \\
\hline IT & $\begin{array}{l}271.0 \pm \\
10.7^{\dagger \ddagger}\end{array}$ & $\begin{array}{l}267.6- \\
274.4\end{array}$ & $\begin{array}{l}250.0 \pm \\
22.2^{\dagger \S}\end{array}$ & $\begin{array}{l}245.1- \\
254.9\end{array}$ & $\begin{array}{l}243.2 \pm \\
18.9^{\ddagger \S}\end{array}$ & $\begin{array}{l}239.0- \\
247.4\end{array}$ & $<0.001$ \\
\hline SH & $\begin{array}{l}291.7 \pm \\
12.2^{\dagger \ddagger}\end{array}$ & $\begin{array}{l}287.8- \\
295.6\end{array}$ & $\begin{array}{l}275.90 \pm \\
15.9^{\dagger \S}\end{array}$ & $\begin{array}{l}272.4- \\
279.4\end{array}$ & $\begin{array}{l}265.1 \pm \\
14.4^{\ddagger \S}\end{array}$ & $\begin{array}{l}261.9- \\
268.3\end{array}$ & $<0.001$ \\
\hline IH & $\begin{array}{l}288.7 \pm \\
12.5^{\dagger \ddagger}\end{array}$ & $\begin{array}{l}284.7- \\
292.6\end{array}$ & $\begin{array}{l}264.2 \pm \\
23.4^{\dagger \S}\end{array}$ & $\begin{array}{l}259.1- \\
269.4\end{array}$ & $\begin{array}{l}253.2 \pm \\
21.7^{\ddagger 5}\end{array}$ & $\begin{array}{l}248.4- \\
258.0\end{array}$ & $<0.001$ \\
\hline
\end{tabular}




\begin{tabular}{|c|c|c|c|c|c|c|c|}
\hline \multicolumn{8}{|c|}{ Mean mGCL thickness } \\
\hline \multirow[b]{2}{*}{ Quadrant } & \multicolumn{2}{|c|}{ Normal } & \multicolumn{2}{|c|}{$\begin{array}{l}\text { Mild-moderate } \\
\text { glaucoma }\end{array}$} & \multicolumn{2}{|c|}{$\begin{array}{l}\text { Advanced- } \\
\text { severe glaucoma }\end{array}$} & \multirow[b]{2}{*}{$P$-value* } \\
\hline & $\begin{array}{l}\text { Mean } \\
\pm \text { SD } \\
(\mu \mathrm{m})\end{array}$ & $\begin{array}{l}95 \% \mathrm{Cl} \\
(\mu \mathrm{m})\end{array}$ & $\begin{array}{l}\text { Mean } \\
\pm S D \\
(\mu \mathrm{m})\end{array}$ & $\begin{array}{l}95 \% \mathrm{Cl} \\
(\mu \mathrm{m})\end{array}$ & $\begin{array}{l}\text { Mean } \pm \\
\text { SD }(\mu \mathrm{m})\end{array}$ & $\begin{array}{l}95 \% \mathrm{Cl} \\
(\mu \mathrm{m})\end{array}$ & \\
\hline SN & $\begin{array}{l}33.4 \pm \\
3.2^{\dagger \ddagger}\end{array}$ & $\begin{array}{l}32.4- \\
34.4\end{array}$ & $\begin{array}{l}29.6 \pm \\
3.1^{\dagger \S}\end{array}$ & $\begin{array}{l}28.9- \\
30.3\end{array}$ & $\begin{array}{l}26.3 \pm \\
5.1^{\ddagger \S}\end{array}$ & $\begin{array}{l}25.1- \\
27.4\end{array}$ & $<0.001$ \\
\hline IN & $\begin{array}{l}32.2 \pm \\
3.2^{\ddagger \ddagger}\end{array}$ & $\begin{array}{l}31.1- \\
33.2\end{array}$ & $\begin{array}{l}28.6 \pm \\
4.1^{\dagger \S}\end{array}$ & $\begin{array}{l}27.7- \\
29.4\end{array}$ & $\begin{array}{l}23.8 \pm \\
4.6^{\ddagger \S}\end{array}$ & $\begin{array}{l}22.8- \\
24.8\end{array}$ & $<0.001$ \\
\hline ST & $\begin{array}{l}31.7 \pm \\
3.2^{\dagger \ddagger}\end{array}$ & $\begin{array}{l}30.7- \\
32.7\end{array}$ & $\begin{array}{l}26.5 \pm \\
3.8^{\dagger \S}\end{array}$ & $\begin{array}{l}25.7- \\
27.4\end{array}$ & $\begin{array}{l}20.2 \pm \\
4.4^{\ddagger \S}\end{array}$ & $\begin{array}{l}19.2- \\
21.2\end{array}$ & $<0.001$ \\
\hline IT & $\begin{array}{l}30.8 \pm \\
2.9^{\dagger \ddagger}\end{array}$ & $\begin{array}{l}29.8- \\
32.7\end{array}$ & $\begin{array}{l}25.7 \pm \\
4.6^{\dagger \S}\end{array}$ & $\begin{array}{l}24.7- \\
26.7\end{array}$ & 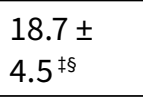 & $\begin{array}{l}17.7- \\
19.7 \\
\end{array}$ & $<0.001$ \\
\hline SH & $\begin{array}{l}32.6 \pm \\
2.9^{\dagger \ddagger}\end{array}$ & $\begin{array}{l}31.6- \\
33.5\end{array}$ & $\begin{array}{l}28.1 \pm \\
3.2^{\dagger \S}\end{array}$ & $\begin{array}{l}27.4- \\
28.8\end{array}$ & $\begin{array}{l}23.2 \pm \\
4.4^{\ddagger \S}\end{array}$ & $\begin{array}{l}22.3- \\
24.2\end{array}$ & $<0.001$ \\
\hline IH & $\begin{array}{l}32.0 \pm \\
2.8^{\dagger \ddagger}\end{array}$ & $\begin{array}{l}31.1- \\
32.9\end{array}$ & $\begin{array}{l}27.1 \pm \\
4.0^{\dagger \S}\end{array}$ & $\begin{array}{l}26.3- \\
28.0\end{array}$ & $\begin{array}{l}21.3 \pm \\
4.3^{\ddagger \S}\end{array}$ & $\begin{array}{l}20.3- \\
22.2)\end{array}$ & $<0.001$ \\
\hline
\end{tabular}

$\mathrm{Cl}$ : confidence interval; IH: inferior hemisphere; IN: inferior nasal; IT: inferior temporal; mGCL: macular ganglion cell layer; mRT: macular retinal thickness; SD: standard deviation; $\mathrm{SH}$ : superior hemisphere; $\mathrm{SN}$ : superior nasal; ST: superior temporal ${ }^{*} P$-values show significance of one-way ANOVA analyses.

${ }^{\dagger}$ Significant $(P<0.05)$ in pairwise comparison (post-hoc LSD) of normal vs mild-moderate glaucoma.

FSignificant $(P<0.05)$ in pairwise comparison (post-hoc LSD) of normal vs advanced-severe glaucoma

${ }^{\S}$ Significant $(P<0.05)$ in pairwise comparison (post-hoc LSD) of mild-moderate vs advanced-severe glaucoma 


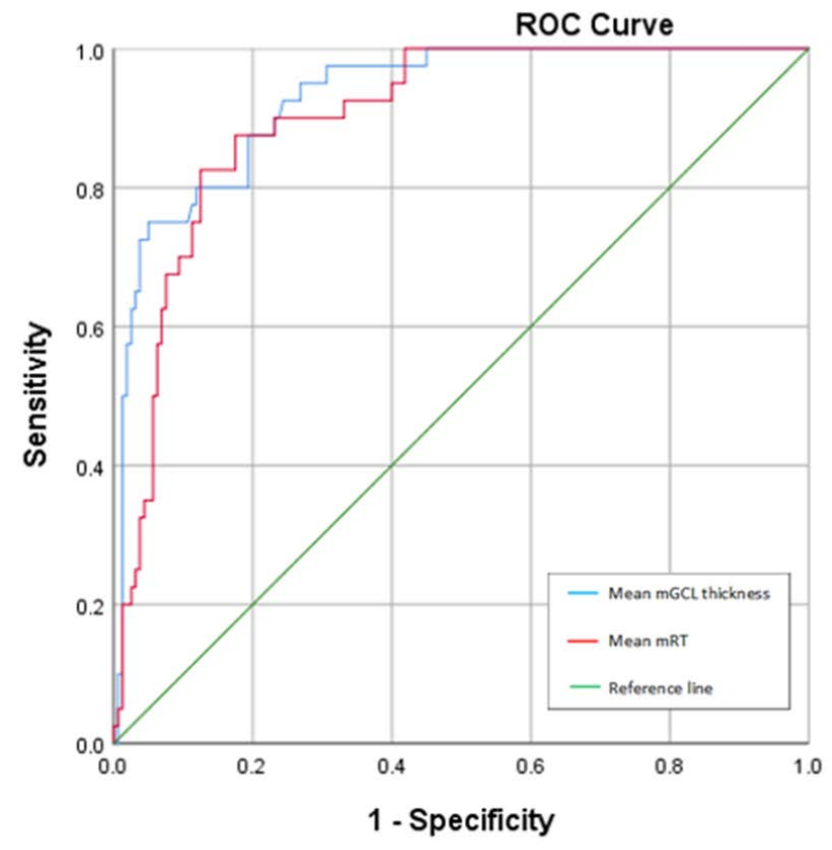

\begin{tabular}{|c|c|c|c|c|c|c|}
\hline \multirow{2}{*}{ Parameters } & \multirow{2}{*}{$\begin{array}{l}\text { Cut-off } \\
\text { value }\end{array}$} & \multirow{2}{*}{$\begin{array}{c}\text { Sensitivity, } \\
\%\end{array}$} & \multirow{2}{*}{$\begin{array}{c}\text { Specificity, } \\
\%\end{array}$} & \multicolumn{2}{|c|}{ Glaucoma } & \multirow{2}{*}{$P$-value } \\
\hline & & & & AUROC & $95 \% \mathrm{Cl}$ & \\
\hline Mean mRT & $<274.88$ & 90 & 75 & 0.901 & $\begin{array}{c}0.856- \\
0.947\end{array}$ & $<0.001$ \\
\hline $\begin{array}{c}\text { Mean } \\
\text { mGCL } \\
\text { thickness }\end{array}$ & $<27.94$ & 93 & 74 & 0.929 & $\begin{array}{c}0.890- \\
0.968\end{array}$ & $<0.001$ \\
\hline
\end{tabular}

Fig. 3. Receiver operating characteristic (ROC) curves and table showing the diagnostic capabilities and accuracy of mean $\mathrm{mRT}$ and $\mathrm{mGCL}$ thickness in differentiating glaucoma from normal subjects. mRT: macular retinal thickness; mGCL: macular ganglion cell layer; AUROC: area under the receiver operating characteristic; $\mathrm{Cl}$ : confidence interval. 
Table 3. Diagnostic capabilities and accuracy of mean macular retinal thickness and macular ganglion cell layer thickness in differentiating different stages of glaucoma subjects

\begin{tabular}{|c|c|c|c|c|c|c|}
\hline $\begin{array}{l}\text { Para- } \\
\text { meters }\end{array}$ & $\begin{array}{l}\text { Glaucoma } \\
\text { stage }\end{array}$ & $\begin{array}{l}\text { Cut-off } \\
\text { value } \\
(\mu \mathrm{m})\end{array}$ & $\begin{array}{l}\text { Sensi- } \\
\text { tivity, } \\
\%\end{array}$ & $\begin{array}{l}\text { Speci- } \\
\text { ficity, } \\
\%\end{array}$ & AUROC & $95 \% \mathrm{Cl}$ \\
\hline \multirow{4}{*}{$\begin{array}{l}\text { Mean } \\
\text { mRT }\end{array}$} & Mild & 274.9 & 90 & 55 & 0.710 & $0.630-0.791$ \\
\hline & Moderate & 266.5 & 78 & 51 & 0.649 & $0.529-0.769$ \\
\hline & Advanced & 260.4 & 66 & 50 & 0.596 & $0.471-0.720$ \\
\hline & Severe & 257.5 & 60 & 54 & 0.583 & $0.457-0.709$ \\
\hline \multirow{4}{*}{$\begin{array}{l}\text { Mean } \\
\text { mGCL } \\
\text { thickness }\end{array}$} & Mild & 28.9 & 88 & 53 & 0.878 & $0.824-0.932$ \\
\hline & Moderate & 26.7 & 80 & 46 & 0.679 & $0.562-0.797$ \\
\hline & Advanced & 23.5 & 81 & 60 & 0.768 & $0.665-0.871$ \\
\hline & Severe & 22.1 & 73 & 62 & 0.695 & $0.578-0.811$ \\
\hline
\end{tabular}

AUROC: area under the receiver operating characteristic; $\mathrm{Cl}$ : confidence interval; mGCL: macular ganglion cell layer; mRT: macular retinal thickness 
Table 4. Diagnostic capabilities and accuracy of mean macular retinal thickness and macular ganglion cell layer thickness in differentiating glaucoma from normal subjects according to different quadrants of the posterior pole

\begin{tabular}{|c|c|c|c|c|c|c|c|}
\hline & & & Sensi- & Spec- & Glaucor & & \\
\hline & rant & value & $\begin{array}{l}\text { tivity } \\
\text { (\%) }\end{array}$ & $\begin{array}{l}\text { ificity } \\
\text { (\%) }\end{array}$ & AUROC & $95 \% \mathrm{Cl}$ & $P$-value \\
\hline & SN & $\leq 293.91$ & 90 & 71 & 0.866 & $\begin{array}{l}0.805- \\
0.927\end{array}$ & $<0.001$ \\
\hline & IN & $\leq 283.41$ & 90 & 71 & 0.895 & $\begin{array}{l}0.839- \\
0.951\end{array}$ & $<0.001$ \\
\hline $\begin{array}{l}\text { Mean } \\
\text { mRT }\end{array}$ & ST & $\leq 258.75$ & 90 & 62 & 0.856 & $\begin{array}{l}0.798- \\
0.913\end{array}$ & $<0.001$ \\
\hline & IT & $\leq 259.94$ & 90 & 79 & 0.887 & $\begin{array}{l}0.838- \\
0.936\end{array}$ & $<0.001$ \\
\hline & SH & $\leq 277.63$ & 90 & 71 & 0.875 & $\begin{array}{l}0.823- \\
0.926\end{array}$ & $<0.001$ \\
\hline & IH & $\leq 268.41$ & 90 & 70 & 0.904 & $\begin{array}{l}0.859- \\
0.950\end{array}$ & $<0.001$ \\
\hline & SN & $\leq 29.09$ & 90 & 58 & 0.857 & $\begin{array}{l}0.793- \\
0.921\end{array}$ & $<0.001$ \\
\hline & IN & $\leq 28.09$ & 90 & 63 & 0.862 & $\begin{array}{l}0.802- \\
0.921\end{array}$ & $<0.001$ \\
\hline $\begin{array}{l}\text { Mean } \\
\text { mGCL }\end{array}$ & ST & $\leq 28.03$ & 90 & 81 & 0.930 & $\begin{array}{l}0.887- \\
0.973\end{array}$ & $<0.001$ \\
\hline $\begin{array}{l}\text { thick- } \\
\text { ness }\end{array}$ & IT & $\leq 28.63$ & 93 & 88 & 0.941 & $\begin{array}{l}0.905- \\
0.977\end{array}$ & $<0.001$ \\
\hline & SH & $\leq 28.55$ & 93 & 73 & 0.917 & $\begin{array}{l}0.872- \\
0.963\end{array}$ & $<0.001$ \\
\hline & IH & $\leq 27.53$ & 90 & 70 & 0.922 & $\begin{array}{l}0.882- \\
0.963\end{array}$ & $<0.001$ \\
\hline
\end{tabular}

AUROC: area under the receiver operating characteristic; $\mathrm{Cl}$ : confidence interval; IH: inferior hemisphere; IN: inferior nasal; IT: inferior temporal; mGCL: macular ganglion cell layer; mRT: macular retinal thickness; SH: superior hemisphere; SN: superior nasal; ST: superior temporal 
The discrimination ability of mean $\mathrm{mRT}$ and $\mathrm{mGCL}$ thickness deteriorated with increasing severity of glaucoma (Table 3). Mean mGCL thickness performed better than mRT overall. Both $\mathrm{mRT}$ and $\mathrm{mGCL}$ thickness showed higher sensitivity in diagnosing mild glaucoma compared to other groups of glaucoma (mRT AUROC: 0.71, mGCL AUROC: 0.87).

The diagnostic power of the PPTM in differentiating glaucoma from normal subjects was greater in quadrant analysis. In particular, the inferior hemisphere quadrant for mean mRT (AUROC: $0.90,95 \%$, confidence interval 0.86-0.95, $P<0.001$ ) and inferior temporal quadrant for mGCL thickness (AUROC: 0.94, 95\%, confidence interval 0.90-0.97, $P<0.001$ ) (Table 4).

\section{Discussion}

In this study, we measured $\mathrm{mRT}$ and $\mathrm{mGCL}$ thickness in glaucomatous and non-glaucomatous patients using the Spectralis SD-OCT PPTM. The mean mRT of the posterior pole in the normal population in this study is compatible with previous studies done with either the PPTM analysis or Early Treatment of Diabetic Retinopathy Study subfield retinal thickness analysis protocol..$^{8,911,15}$ Our study found greater mean mGCL thickness values in the normal population when compared to a similar study done by Hiroshi et al. ${ }^{2}$ Their study, however, used a different protocol for measurement of ganglion cell layer thickness without the PPTM's macular segmentation software.

Our results corresponded well with a study by Sandeep et al. ${ }^{6}$ that found retinal thickness was highest in the nasal field of the Early Treatment of Diabetic Retinopathy Study map. Mean mRT was greater at the nasal quadrant in our study due to the overlap of the temporal vascular arcades. A new OCT segmentation algorithm that excludes retinal vessels from retinal thickness is currently under development to increase the accuracy of OCT parameters. In this study, mean mGCL was thickest at the superior nasal quadrant, followed by the inferior nasal quadrant, similar to a study by Ana et al. ${ }^{5}$ This finding is most likely attributable to the papillomacular bundle, which is relatively resistant to glaucomatous change and is preserved until the advanced stages of the disease. ${ }^{16} \mathrm{~A}$ literature review also shows that, in the nasal retina, there are $41 \%$ more ganglion cells than in the temporal retina. ${ }^{17}$

Our study found that, using the Spectralis SD-OCT PPTM's macular segmentation software, a mean mRT of less than $274.9 \mu \mathrm{m}$ and mean mGCL thickness of less than $27.9 \mu \mathrm{m}$ should alert the clinician about the possibility of glaucoma. Both parameters seem to be good predictors to discriminate glaucoma from normal eyes, as both parameters achieve a sensitivity of at least $90 \%$ and a specificity of more than $70 \%$. This result is in agreement with results from studies showing that the inner macular layers of the retina are more precise in differentiating between normal and glaucomatous eyes. These measurements also correspond to peripap- 
illary retinal nerve fibre layer thickness. ${ }^{2}$

The discrimination ability of $\mathrm{mRT}$ and $\mathrm{mGCL}$ thickness performed worse with more severe grades of glaucoma. One of the major problems of monitoring structural changes in patients with severe glaucoma by using macular OCT is the floor effect, the point at which no further structural loss is detectable. ${ }^{18}$ This floor effect is probably due to the presence of residual tissue such as blood vessels and glial cells. ${ }^{19}$

Comparing between $\mathrm{mRT}$ and $\mathrm{mGCL}$ thickness, our study demonstrated that mean $\mathrm{mGCL}$ thickness has better discriminating capabilities in diagnosing different stages of glaucoma. A study done by Tan et al. found that ganglion cell layer thickness measured by SD-OCT has better diagnostic capability compared to the total macular thickness and is statistically equivalent to OCT peripapillary retinal nerve fibre layer measurements. ${ }^{19}$ Studies also show that ganglion cell-inner plexiform layer thickness is superior in recognizing glaucoma progression, and is less likely to reach the measurement floor compared to retinal nerve fibre layer thickness in advanced glaucoma. ${ }^{16,18}$

Macular thickness has been proposed as an early indicator of glaucomatous damage due to the high proportion of retinal ganglion cells present in the macula., ${ }^{4,8}$ To increase the diagnostic power of macular imaging, it is useful to isolate the ganglion cell layer from the rest of the retina, as glaucoma causes the death of cell bodies of retinal ganglion cells, which is the main reason for ganglion cell layer thinning. ${ }^{20}$ We found that mean $\mathrm{mRT}$ and $\mathrm{mGCL}$ thickness are especially helpful in diagnosing mild glaucoma and can be used as a biomarker of early glaucomatous damage before visual field defects are evident. Functional visual field loss is only evident when at least $25-40 \%$ of retinal ganglion cells have been lost. ${ }^{6}$ Significant structural loss of retinal ganglion cells can be revealed 5 years earlier prior to the visual field deficit. ${ }^{8,9}$

The AUROC for mean $\mathrm{mRT}$ in the inferior hemisphere was greater than in other quadrants (range 0.859-0.950) in differentiating glaucoma from normal subjects and was statistically significant, $P<0.001$. This result was similar to those in previous studies showing that inferior macular thickness has high discriminating power with an AUROC range of $0.61-0.83 .{ }^{15}$ Our results also suggested that, among all the parameters, mean $\mathrm{mGCL}$ thickness at the inferior temporal quadrant has the best diagnostic performance (AUROC: 0.941 ) in distinguishing glaucoma from normal eyes. A literature review showed that the inferior temporal sector is the most frequent region displaying ganglion cell layer thinning in the macula, which is compatible with the inferior peripapillary area revealing retinal nerve fibre layer defects most commonly. ${ }^{21}$

Our study is not without its limitations. We did not compare the diagnostic accuracy of Spectralis PPTM macular imaging with the more commonly used peripapillary retinal nerve fibre layer measurement. Additionally, we did not compare the diagnostic accuracy of $\mathrm{mGCL}$ with the ganglion cell complex, which comprises 
the three innermost layers of the retina: the retinal nerve fibre layer, the ganglion cell layer, and the inner plexiform layer. While it has been shown in this study that mean $\mathrm{mRT}$ and $\mathrm{mGCL}$ thickness measurements perform well in discriminating glaucoma from normal eyes, how it compares to OCT measurements of the retinal nerve fibre layer and ganglion cell complex is beyond the scope of this study. A comparison of the structure-function relationship of macular imaging with the visual field test was also not performed in this study, as this has been done previously in several studies. Lastly, due to the cross-sectional nature of this study, the question of whether macular imaging is useful not only for diagnosis but also for monitoring of glaucoma patients could not be addressed. Future studies could explore this very promising premise on glaucoma patients.

\section{Conclusion}

The Spectralis SD-OCT PPTM offers an alternative imaging method to detect and diagnose early glaucoma. Our study showed that mean $\mathrm{mRT}$ and $\mathrm{mGCL}$ thickness measured by PPTM has excellent diagnostic accuracy with good sensitivity and specificity to discern between normal and glaucomatous eyes. We would highly recommend its role in diagnostic glaucoma imaging, especially in cases when other methods such as peripapillary retinal nerve fibre layer and/or visual field tests are equivocal.

\section{Declarations}

\section{Ethics approval and consent to participate}

Ethical approval was obtained prior to the commencement of the study from the Medical Research \& Ethics Committee (NMRR-18-458-39979). Informed consent was obtained from all participants. The study was conducted in accordance with the Declaration of Helsinki.

\section{Competing interests}

None to declare.

\section{Funding}

None to declare.

\section{Acknowledgements}

We would like to acknowledge our statistician, Dr. Sumaiyah bt Mat, postdoctoral research fellow in the Department of Medicine, University of Malaya for her expertise and assistance in running the statistical analysis. 


\section{References}

1. Stein JD, Khawaja AP, Weizer JS. Glaucoma in Adults-Screening, Diagnosis, and Management: A Review. JAMA. 2021 Jan 12;325(2):164-74.

2. Yamada H, Hangai M, Nakano N, et al. Asymmetry analysis of Macular Inner Retinal Layers for Glaucoma Diagnosis. Am J Ophthalmol 2014;158:1318-29. e3.

3. Appukuttan B, Giridhar A, Gopalakrishnan M, Sivaprasad S. Normative Spectral Domain Optical Coherence Tomography Data on Macular and Retinal Nerve Fiber Layer Thickness in Indians. Indian J Ophthalmol 2014;62:316.

4. Martinez JM, Cifuentes P, Berrozpe C, et al. Diagnostic Ability of Macular Nerve Fiber Layer Thickness using New Segmentation Software in Glaucoma Suspects. Invest Ophthalmol Vis Sci 2014;55:8343-8.

5. Loduca AL, Zhang C, Zelkha R, Shahidi M. Thickness Mapping of Retinal Layers by Spectral-Domain Optical Coherence Tomography. Am J Ophthalmol 2010;150:849-55.

6. Grover S, Murthy RK, Brar VS, Chalam KV. Normative Data for Macular Thickness by High-Definition Spectral-Domain Optical Coherence Tomography (Spectralis). Am J Ophthalmol 2009;148:266-71.

7. Asrani S, Rosdahl JA, Allingham RR. Novel software strategy for glaucoma diagnosis: asymmetry analysis of retinal thickness. Archives of ophthalmology. 2011 Sep 12;129(9):1205-11.

8. Rolle T, Manerba L, Lanzafame P, Grignolo FM. Diagnostic Power of Macular Retinal Thickness Analysis and Structure-Function Relationship in Glaucoma Diagnosis using SPECTRALIS OCT. Curr Eye Res 2016;41:667-75.

9. Jacobsen AG, Bendtsen MD, Vorum H, et al. Normal Value Ranges for Central Retinal Thickness Asymmetry in Healthy Caucasian Adults Measured by SPECTRALIS SD-OCT Posterior Pole Asymmetry Analysis. Invest Ophthalmol Vis Sci 2015;56:3875-82.

10. Miraftabi A, Amini N, Morales E, et al. Macular SD-OCT Outcome Measures: Comparison of Local Structure-Function Relationships and Dynamic Range. Invest Ophthalmol Vis Sci 2016;57:4815-23.

11. Kafieh R, Rabbani H, Hajizadeh F, et al. Thickness Mapping of Eleven Retinal Layers Segmented using the Diffusion Maps Method in Normal Eyes. J Ophthalmol 2015;2015.

12. Mills RP, Budenz DL, Lee PP, Noecker RJ, Walt JG, Siegartel LR, Evans SJ, Doyle JJ. Categorizing the stage of glaucoma from pre-diagnosis to end-stage disease. American journal of ophthalmology. 2006 Jan 1;141(1):24-30.

13. Foster PJ, Buhrmann R, Quigley HA, Johnson GJ. The definition and classification of glaucoma in prevalence surveys. British journal of ophthalmology. 2002 Feb 1;86(2):238-42.

14. Michelessi M, Riva I, Martini E, et al. Macular Versus Nerve Fibre Layer versus Optic Nerve Head Imaging for Diagnosing Glaucoma at Different Stages of the Disease: Multicenter Italian Glaucoma Imaging Study. Acta Ophthalmol 2019;97:e207-e15.

15. Dave P, Shah J. Diagnostic Accuracy of Posterior Pole Asymmetry Analysis Parameters of Spectralis Optical Coherence Tomography in Detecting Early Unilateral Glaucoma. Indian J Ophthalmol 2015;63:837.

16. Shin JW, Sung KR, Lee GC, et al. Ganglion Cell-Inner Plexiform Layer Change Detected by Optical Coherence Tomography Indicates Progression in Advanced Glaucoma. Ophthalmology 2017;124:146674.

17. Curcio CA, Allen KA. Topography of Ganglion Cells in Human Retina. J Comp Neurol 1990;300:5-25. 
18. Bowd C, Zangwill LM, Weinreb RN, et al. Estimating Optical Coherence Tomography Structural Measurement Floors to Improve Detection of Progression in Advanced Glaucoma. Am J Ophthalmol 2017;175:37-44.

19. Tan O, Chopra V, Lu AT H, et al. Detection of Macular Ganglion Cell Loss in Glaucoma by Fourier-Domain Optical Coherence Tomography. Ophthalmology 2009;116:2305-14. e2.

20. Nakano N, Hangai M, Nakanishi H, et al. Macular Ganglion Cell Layer Imaging in Preperimetric Glaucoma with Speckle Noise-Reduced Spectral Domain Optical Coherence Tomography. Ophthalmology 2011;118:2414-26.

21. Akman A, Bayer A, Nouri K. Optical Coherence Tomography in Glaucoma: A Practical Guide: Springer; 2018. 